Jurnal Akuakultur Sungai dan Danau Vol. 4 No. 1 Tahun 2019 Hal. 1 - 8

ISSN Print 2503-4766

ISSN Online 2597-8837

\title{
LAMA WAKTU DAN PERKEMBANGAN TELUR IKAN PATIN SIAM (Pangasius hypophtalmus) DALAM CORONG PENETASAN DENGAN KEPADATAN YANG BERBEDA
}

\author{
${ }^{1)}$ Donly Sitinjak, ${ }^{2)}$ Muhammad Sugihartono, dan ${ }^{3)}$ Muarofah Ghofur \\ Alumni Program Studi Budidaya Perairan, Fakultas Pertanian Universitas Batanghari \\ Program Studi Budidaya Perairan, Fakultas Pertanian Universitas Batanghari \\ Jl. Slamet Riyadi, Broni Jambi, 36122. Telp. +6074160103 \\ ${ }^{3)}$ Email korespondensi : muarofah_ghofur@yahoo.com
}

\begin{abstract}
Catfish is one of the introductory freshwater fish commodities from Thailand which is rapidly developing its culture in Indonesia. Many factors influence the success of hatchery, one of which is the level of egg density during hatching, high density can cause low hatchability and the slow phase of development of eggs, this is because the higher the density of eggs, the narrower the chance of egg embryos to developing this can inhibit egg development (Marzuki, 2013). The purpose of this research is to know the optimal density of long time hatchery and the development of Patin Siamese fish eggs. The method of research conducted is descriptive with 4 treatments and 3 repeats, wherein each treatment is: treatment A 1000 grains/Liter, treatment B 1200 grains/liter, C 1400 grains/Liter treatment and D 1600 grains/liter. The parameters observed were: Hatching time, egg morphology and water quality. The results show for the best treatment of hatching time were treatment B 25.35'hours, the morphology of the eggs was obtained from the color and size of each step is not different.
\end{abstract}

Keywords : density, hatching time, siamese catfish, water quality

\begin{abstract}
Abstrak
Ikan patin adalah salah satu komoditi ikan air tawar introduksi dari Thailand yang budidayanya pesat di Indonesia. Banyak faktor yang mempengaruhi keberhasilan pada masa pembenihan, salah satunya adalah tingkat kepadatan telur pada saat penetasan, kepadatan yang tinggi dapat menyebabkan rendahnya daya tetas dan lambatnya fase perkembangan telur, hal ini disebabkan karena semakin tinggi kepadatan telur maka semakin sempit/kecil kesempatan embrio telur untuk berkembang hal ini bisa menghambat perkembangan telur (Marzuki, 2013). Tujuan penelitian ini adalah untuk mengetahui kepadatan optimal terhadap lama waktu penetasan dan perkembangan telur ikan patin siam. Metode penelitian yang dilakukan adalah secara deskriptif dengan 4 perlakuan dan 3 ulangan, dimana masing-masing perlakuan tersebut adalah : perlakuan A 1000 butir/liter, perlakuan B 1200 butir/liter, perlakuan C 1400 butir/liter dan perlakuan D 1600 butir/liter. Parameter yang diamati adalah : lama waktu penetasan, morfologi telur dan
\end{abstract}


Jurnal Akuakultur Sungai dan Danau Vol. 4 No. 1 Tahun 2019 Hal. 1 - 8

ISSN Print 2503-4766

ISSN Online 2597-8837

kualitas air. Hasil penelitian yang diperoleh untuk perlakuan terbaik lama waktu penetasan adalah perlakuan B 25.35'jam, morfologi telur didapatkan dari warna dan ukuran setiap perlakuan tidak berbeda.

Kata kunci : Ikan patin siam, kepadatan, kualitas air, lama waktu penetasan,

\section{PENDAHULUAN}

Ikan patin adalah salah satu komiditi ikan air tawar introduksi dari Thailand yang pesat perkembangan budidayanya di Indonesia (Hamid dan Setyowibowo, 2010). Hal tersebut terkait dengan tingginya tingkat konsumsi masyarakat Indonesia terhadap ikan patin, tingginya permintaan konsumsi ikan patin secara langsung akan berpengaruh terhadap ketersediaan benih dalam jumlah yang banyak dan tersedia secara kontinyu, sementara untuk menghasilkan benih yang banyak dalam waktu tertentu cenderung mengalami kesulitan.

Banyak faktor yang mempengaruhi keberhasilan pada masa pembenihan, salah satunya adalah tingkat kepadatan telur pada saat penetasan, kepadatan yang tinggi dapat menyebabkan rendahnya daya tetas dan lambatnya fase perkembangan telur, hal ini disebabkan karena semakin tinggi kepadatan telur maka semakin sempit/kecil kesempatan embrio telur untuk berkembang hal ini bisa menghambat perkembangan telur (Marzuki, 2013).

Menurut Hermawan et al (2014), kepadatan dalam pembenihan membawa dampak kurang baik terhadap kelestarian dan kesehatan lingkungan yang berupa penurunan kualitas lingkungan air budidaya. Wijaya et al (2014) menyatakan bahwa kualitas air merupakan faktor yang penting dalam pertumbuhan ikan. Semakin tinggi kepadatan maka akan berpengaruh terhadap kualitas air seperti nitrat, nitrit, ammonia, DO, pH. Hal ini menyebabkan rendahnya laju pertumbuhan ikan.

Menurut Slembrouck et al (2005), tingkat kepadatan telur pada proses penetasan dalam corong sebanyak 10 gram/l (skala BBAT Jambi), dengan jumlah telur per 1 gram adalah 1200 butir (Hamid dan Setyowibiwo, 2010). Dari referensi tersebut penulis mencoba untuk melakukan penelitian kepadatan telur ikan patin dengan skala labor/kecil dalam corong penetasan dengan kepadatan jumlah telur 1200 butir/l, untuk mengetahui tingkat kepadatan telur ikan patin siam (P. hypophtalamus) terhadap lama waktu dan daya tetas telur dalam corong penetasan. 


\section{METODOLOGI PENELITIAN}

Kegiatan Penelitian Tingkat Kepadatan Telur Ikan Patin siam ( $P$. hypophtalamus) terhadap lama waktu dan daya tetas telur dalam corong penetasan ini dilaksanakan pada bulan Maret sampai April 2018 di UPR (Unit Pembenihan Rakyat) Kenali Besar dan. Bahan penelitian yang digunakan telur ikan patin siam, ovaprim, NaCL 0,9, aquabides, induk ikan patin siam. Peralatan yang digunakan dalam penelitian ini adalah corong penetasan, mikroskop, serok halus, aerator, sendok, alat tulis, kamera, mistar, gelas ukur, alat kualitas air, aquarium, spuit 3 ML. Penelitian ini dilakukan secara deskriptif. Untuk mengetahui hasil optimal, maka dilakukan dengan 4 (empat) perlakuan dan 3 (tiga) kali ulangan. Masing masing perlakuan tersebut adalah perlakuan A kepadatan 1000 butir/liter, perlakuan B dengan kepadatan 1200 butir/liter, kemudian perlakuan C dengan kepadatan 1400 butir/liter, dan perlakuan D dengan kepadatan 1600 butir/liter.

Induk ikan patin siam (P.hyhpopthalmus) yang digunakan berasal dari BPBAT sungai gelam. Tahapan kegiatan penelitian dimulai dengan pemijahan induk secara intensif. Sebelum dipijahkan induk ikan disuntik terlebih dahulu menggunakan ovaprim dengan dosis $0,5 / \mathrm{kg}$. Penyuntikan dilakukan $1 \mathrm{kali}$, induk akan ovulasi 12 jam setelah penyuntikan, setelah induk ovulasi telur dimasukan ke dalam masing-masing corong penetasan yang telah di isi air sebanyak satu liter sebanyak 12 buah. Masing-masing wadah diberi label sesuai dengan pengacakan dan dilengkapi aerasi dengan tekanan yang kecil. Air yang digunakan dalam penelitian ini adalah air sumur. Sebelum digunakan air tersebut diendapkan terlebih dahulu untuk menghilangkan sedimentasi.

\section{Parameter Yang Diamati}

\section{Lama Waktu Penetasan Telur}

Lama waktu penentasan adalah waktu yang dibutuhkan telur untuk dapat menetas. Pengamatan lama waktu penetasan diamati menggunakan Mikroskop.

\section{Perkembangan Telur}

Perkembangan telur meliputi ukuran, fase perkembangan dan warna telur. Diameter telur diukur dengan menggunakan mistar dan diamati di bawah mikroskop, fase perkembangan telur dan warna telur juga di amati dengan menggunakan mikroskop.

\section{Kualitas Air}

Pengukuran parameter kualitas air meliputi suhu, $\mathrm{pH}$, oksigen terlarut, karbondioksida, Ammonia.

\section{Analisis Data}

Data yang diproleh selama penelitian ditabulasikan kedalam bentuk Tabel, kemudian dianalisis dengan analisis deskriptif. 


\section{Lama Waktu Penetasan Telur}

\section{HASIL DAN PEMBAHASAN}

Berdasarkan hasil analisis dan rata-rata lama waktu penetasan telur ikan patin siam ( $P$. hypophtalmus) dengan tingkat kepadatan yang berbeda dalam corong penetasan disajikan pada tabel 1 .

Tabel 1. Rata-rata lama waktu penetasan telur ikan patin siam (P.hypophtalmus)

\begin{tabular}{cc}
\hline Perlakuan & $\begin{array}{c}\text { Rata-Rata Lama Waktu Penetasan } \\
\text { (Jam.menit) }\end{array}$ \\
\hline A & $25.54^{\prime}$ \\
B & $25.35^{\prime}$ \\
C & $25.37^{\prime}$ \\
D & $25.46^{\prime}$ \\
\hline
\end{tabular}

Dari tabel diatas rata-rata yang didapat menunjukan bahwa tingkat kepadatan yang berbeda tidak mempengaruhi lama waktu penetasan, didalam penelitian ini didapatkan lama waktu penetasan pada perlakuan A kepadatan 1000 butir/liter yaitu 25,54 jam, perlakuan B dengan kepadatan 1200 butir/liter yaitu 25,35 jam, kemudian perlakuan $\mathrm{C}$ dengan kepadatan 1400 butir/liter yaitu 25,37 jam, dan perlakuan D dengan kepadatan 1600 butir/liter yaitu 25,46 jam.

Dari hasil ini diduga dipengaruhi oleh faktor cahaya, karena cahaya adalah faktor yang dapat mempercepat proses penetasan telur ikan. Cahaya yang baik untuk penetasan telur ikan adalah dengan jumlah cahaya yang masuk tidak terlalu besar sehingga proses perkembangan telur dapat berjalan seimbang. Pada penelitian ini diduga pada kepadatan 1200 butir/liter memiliki persentasi masuknya cahaya terbaik dan mampu menyebar kesetiap telur sehingga telur dapat menetas dengan cepat. Untuk perlakuan C dan Perlakuan D dengan tingkat kepadatan 1400 butir/liter dan 1600 butir/liter didapatkan rata-rata lama waktu penetasan 25,37 jam dan 25,46 jam. Lamanya penetasan diakibatkan tingginya tingkat kepdatan telur yang tinggi sehingga mengakibatkan cahaya yang masuk tidak merata menyebar keseluruh telur sehingga mengakibatkan lamanya telur menetas. Sedangakan untuk waktu penetasan terlama di dapat pada perlakuan A kepadatan 1000 butir/liter jarak waktu penetasanya tidak terlalu jauh hal ini diduga cahaya yang masuk ketelur terlalu tinggi dan dapat mengakibatkan lambatnya penetasan, kepadatan yang rendah menyebabkan cahaya yang secara langsung menyinari telur dan bisa mengakibatkan perkembangan embrionya terhampat, sehingga telur itu perlu dinaungi agar bisa menetas sempurna, hal ini didukung oleh Nikolsky dalam Ulyana et al (2018), bahwa faktor yang mempengaruhi penetasan telur ikan salah satunya adalah intensitas cahaya. 


\section{Perkembangan Telur}

Berdasarkan hasil Pengamatan morfologi telur meliputi ukuran telur, fase perkembangan telur dan warna telur. Ukuran telur dapat diamati dibawah mikrosko untuk melihat perubahan diameter telur. Fase perkembangan dan perubahan wana terlur juga diamati dibawah mikroskop. Didapatkan hasilnya yang disajikan pada tabel 2.

Tabel 2. Penetasan telur ikan patin siam ( $P$. hypophtalmus) dengan padat penebaran yang berbeda tidak memberikan pengaruh terhadap morfologi (warna dan ukuran).

\begin{tabular}{ccccc}
\hline Perlakuan & A & B & C & D \\
\hline Warna & Putih Bening & Putih Bening & Putih Bening & Putih Bening \\
\hline Ukuran & $1,5 \mathrm{~mm}$ & $1,5 \mathrm{~mm}$ & $1,5 \mathrm{~mm}$ & $1,5 \mathrm{~mm}$ \\
\hline
\end{tabular}

Dari tabel diatas bisa dilihat bahwa tingkat kepadatan yang berbeda tidak mempengaruhi warna telur serta ukuran telur. Setelah diamati dibawah mikroskop maka didapatkan warna telur seperti tabel diatas yaitu rata-rata berwarna putih bening. Pada saat penetasan telur yang dilakukan dengan padat penebaran yang berbeda warna telur tidak terlalu berbeda siknifikan. Sementara untuk ukuran telur setelah dilakukan pengukuran didapatkan ukuran yang sama yaitu $1,5 \mathrm{~mm}$. Diduga padat penebaran yang berbeda hanya mempengaruhi pergerakan embrio yang semakin aktif dan mempengaruhi proses penetasan.

Sementara untuk perkembangan embrio telur ikan patin siam (P.hypopthalmus) dilakukan Pengamatan perkembangan embrio setiap 2 jam sekali setelah pembuahan. Data fase perkembangan telur disajikan pada tabel 3.

Tabel 3. Fase perkembangan telur pada saat penelitian tingkat kepadatan telur ikan patin siam ( $P$. hypophtalmus) terhadap lama waktu dan daya tetas telur dalam corong penetasan.

\begin{tabular}{|c|c|c|c|c|}
\hline $\begin{array}{c}\text { Waktu } \\
\text { pengamatan }\end{array}$ & & Fase perke & bangan telur & \\
\hline \multirow[b]{2}{*}{1 jam } & $\mathrm{A}$ & B & & D \\
\hline & & & & \\
\hline \multirow[t]{2}{*}{$\begin{array}{c}\text { 2-3 jam } \\
\text { (jam 11-12) }\end{array}$} & & & & \\
\hline & Stadia Morula & Stadia Morula & Stadia Morula & Stadia Morula \\
\hline
\end{tabular}




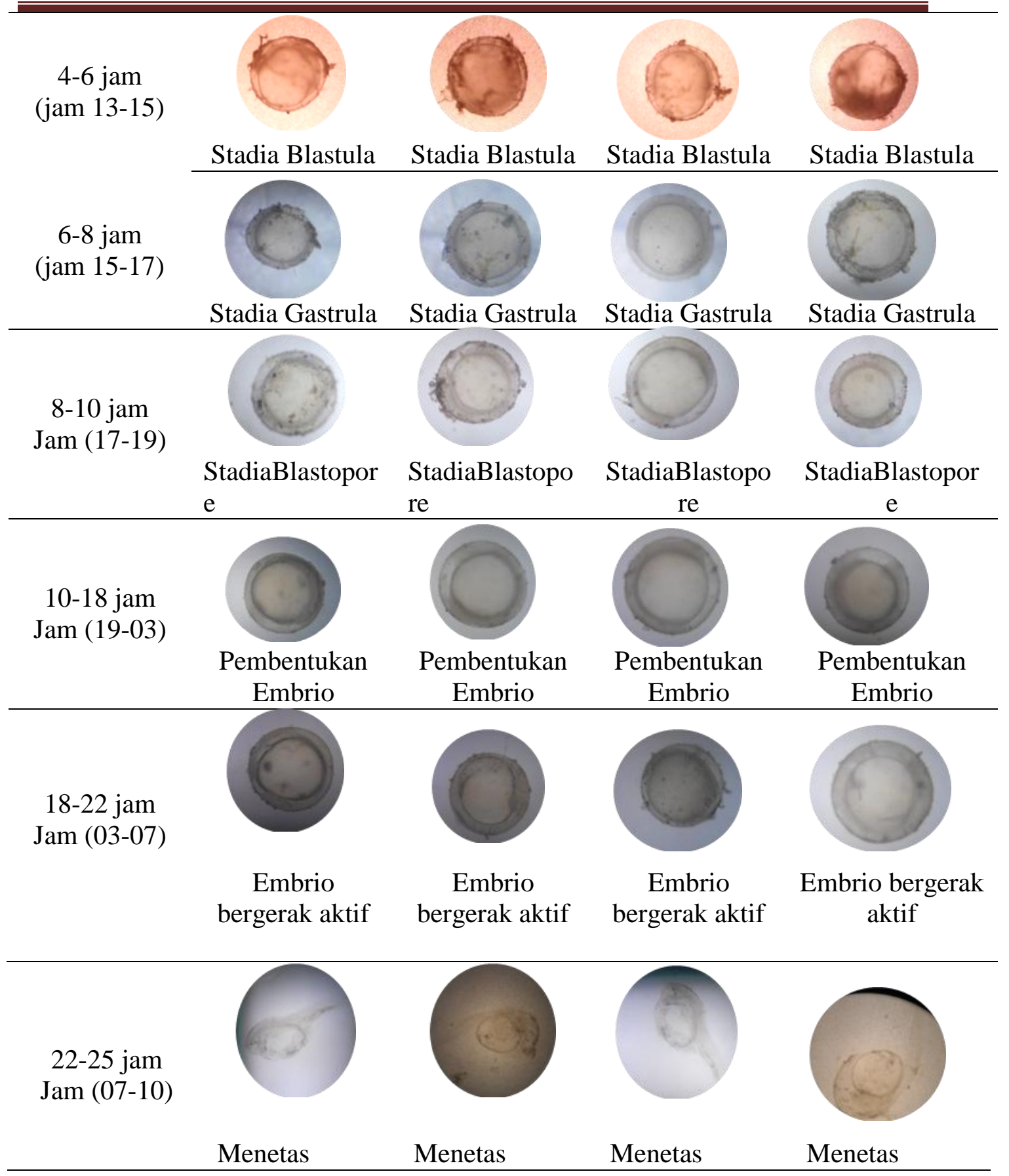

\section{Kualitas Air}

Kualitas air pada penelitian ini didapatkan kisaran suhu $28^{\circ} \mathrm{C}$ kisaran ini masih dalam kondisi yang optimal untuk penetasan telur, Menurut Hadid et al (2014) suhu kisaran optimal untuk penetasan telur antara $27^{\circ} \mathrm{C}-30^{\circ} \mathrm{C}$. Sementara untuk pH selama penelitian didapatkan sebesar 7,1 - 8,2 kisaran $\mathrm{pH}$ ini masih pada kisaran yang baik untuk penetasan telur, hal ini didudukung oleh Hadid et al (2014), yang menyatakan kisaran $\mathrm{pH}$ yang baik untuk penetasan telur adalah 6,99,0. Untuk kisaran oksigen terlarut pada penelitian ini didapat 7,45 - 8,89 ppm 
Jurnal Akuakultur Sungai dan Danau Vol. 4 No. 1 Tahun 2019 Hal. 1 - 8

ISSN Print 2503-4766

ISSN Online 2597-8837

Menurut Hadid et al (2014), kisaran oksigen terlarut yang baik untuk penetasan telur adalah berkisar antara $5-9,0$. Telur - telur membutuhkan oksigen yang cukup untuk penetaan. Untuk nilai karbondioksida didapatkan sebesar 0,0302 0,0534 mg/L. Dan untuk kisaran Ammonia selama penelitian ini didapatkan sebesar 0,0140 - 0,0790 ppm. kisaran ini masih berada dalam konsentrasi yang bisa ditoleril oleh telur ataupun ikan. Untuk penetasan telur kandungan ammonia dihasilkan dari pemecahan nitrogen organik (protein) serta sisa metabolisme telur terutama minyak, kisaran Ammonia yang baik untuk penetasan telur adalah <0,2 $\mathrm{mg} / \mathrm{L}$ (Hadid et al, 2014).

\section{KESIMPULAN}

Berdasarkan penelitian lama waktu dan perkembangan telur ikan patin siam (P. Hypophtalmus) dalam corong penetasan dengan kepadatan yang berbeda didapatkan kesimpulan sebagai berikut : Lama waktu penetasan tercepat selama 25,35 jam pada perlakuan B (1200 butir/liter). Sedangkan untuk warna dan diameter telur tidak memiliki perbedaan pada setiap perlakuan.

Disarankan dalam penetasan telur ikan patin siam ( $P$. hypophtalmus) dalam corong penetasan dengan air satu liter sebaiknya dilakukan pada kepadatan 1200 butir/liter karena waktu penetasannya lebih cepat.

\section{DAFTAR PUSTAKA}

Hadid. Y., M. Syaifudin., M. Amin. 2014. Pengaruh Salinitas Terhadap Daya Tetas Telur Ikan Baung (Hemibagrus nemurus Blkr). Jurnal Akuakultur Rawa Indonesia. Program Studi Akuakultur Fakultas Pertanian UNSRI. ISSN : 2303-2960. Vol. 2 No.1. Hal 78-92.

Hamid. M. A., C. Setyowibowo. 2010. Manual Pembenihan Patin Siam ( Pangasianodon hypophthalmus). Direktorat Jendral Perikanan Budidaya. Balai Budidaya Air Tawar Jambi. 59 Hal.

Hermawan. T. E. S. A., A. Sudaryono., S. B. Prayitno. 2014. Pengaruh Padat Tebar Berbeda Terhadap Pertumbuhan dan Kelulushidupan Benih Lele (Clarias gariepinus). Journal of Aquaculture Management and Technology. Volume. 3.Nomor. 3. Hal. 35-42.

Marzuki. A., 2013. Pengaruh Padat Penebaran Yang Berbeda Terhadap Daya Tetas (Hatcing rate) Telur Ikan Betok (Anabas Testudeineus). Skripsi Program Studi Budidaya Perairan Fakultas Pertanian Universitas Batanghari Jambi. 53 Hal.

Saanin. H. 1968. Taksonomi dan Kunci Identifikasi Ikan Jilid I dan II. Bogor. Slembrouck. J., O. Komarudin., Maskur., M. Legendre. 2005. Petunjuk Teknis Pembenihan Ikan Patin Indonesia Pangasius djambal. Departemen Kelautan dan Perikanan. Jakarta. Hal 79-80. 
Jurnal Akuakultur Sungai dan Danau Vol. 4 No. 1 Tahun 2019 Hal. 1 - 8

Ulyana. U., C.N. Devira., I. Hasri. 2018. Inkubasi Telur Ikan Peres (Osteochilus kappeni) Menggunakan Sistem Corong Dengan Padat Tebar yang Berbeda. Jurnal Ilmiah Mahasiswa Kelautan dan Perikanan Unsyiah.ISSN. 25276395. Volume 3, Nomor 1: 84-91.

Wijaya. O., B. S. Rahardja. Prayoga. 2014. Pengaruh Padat Tebar Ikan Lele Terhadap Laju Pertumbuhan dan Survival Rate pada Sistem Akuaponik. Jurnal Ilmiah Perikanan dan Kelautan. Fakultas Perikanan dan Kelautan Universitas Airlangga. Vol. 6 No. 1. Hal 55-58. 